\title{
A case report of very late stent thrombosis after bare-metal stent implantation
}

\author{
Çıplak metal stent implantasyonu sonrası gelişen çok geç dönem stent trombozu \\ Mustafa Adem Tatlısu*, Serhan Özcan, Emre Aruğaslan, Ahmet Zengin, \\ Mehmet Karaca, Mehmet Eren
}

Cardiology Clinic (M. A. Tatlısu, MD, S. Özcan, MD, E. Aruğaslan, MD, A. Zengin, MD, M. Karaca, MD, Assoc. Prof. M. Eren, MD), Dr. Siyami Ersek Cardiovascular and Thoracic Surgery Center, TR-34752 İstanbul

\begin{abstract}
Stent thrombosis is undesirable complication after percutaneous coronary interventions (PCI), despite contemporary concepts of stents and antiplatelet therapy. Stent thrombosis (ST) is defined by the Academic Research Concortium as: early ( $<30$ days), late (30 days to 1 year), and vey late ( $>1$ year). Risk of very late stent thrombosis is considerably higher in patients with drug-eluting stents (DES), owing to delayed endothelialization. There are several cases very late ST after baremetal stent (BMS) implantation. Our patient presented with ST-elevation myocardial infarction on account of BMS thrombosis 14 years after the implantation.
\end{abstract}

Keywords: Stent thrombosis (ST), Drug-eluting stent (DES), Bare-metal stent (BMS), Percutaneous coronary intervention (PCI), Acute Coronary syndrome (ACS)

\section{Özet}

Güncel stent konseptleri ve antiplatelet tedavilerine rağmen stent trombozu perkütan koroner girişimlerden sonra görülen arzu edilmeyen bir komplikasyondur. Stent trombozu, Academic Research Concortium'a göre erken (<30 gün), geç (30 gün ile 1 yıl arasında) ve çok geç dönem (>1 yıl) olmak üzere üçe ayrılmıştır. Gecikmiş endotelizasyona bağlı olarak çok geç dönem stent trombozları ilaç kaplı stentlerde daha fazla görülmektedir. Hastamız çıplak metal kaplı stent implantasyonundan 14 yıl sonra stent trombozuna bağlı ST elevasyonlu myokard infarktüsü ile başvurmuştur.

Anahtar sözcükler: Stent trombozu, ilaç kaplı stent, çıplak metal stent, perkütan koroner girişim, akut koroner sendrom

Geliş tarihi/Received: October 12, 2013; Kabul tarihi/Accepted: March 10, 2014

*Corresponding author:

Dr. Mustafa Adem Tatlısu, Kardiyoloji Bölümü, Dr. Siyami Ersek Gögüs Kalp ve Damar Cerrahisi Eğitim ve Araştırma Hastanesi, TR-34752 İstanbul. E-mail: ademtatlisu@gmail.com

\section{Introduction}

Generally, very late stent thrombosis is seen in patients with drug-eluting stents, owing to delayed endothelialization. Endothelium grows over the struts in 2 to 4 weeks in patients with bare-metal stents (BMS). Nevertheless, once in a while stent thrombosis can be seen in patients with BMS after years. Despite the low probability of this event, we must keep in mind very late stent thrombosis after BMS implantation.

\section{Case report}

A 49-year-old man who had undergone percutaneous coronary intervention (PCI) for STsegment elevation myocardial infarction with a bare-metal stent (BMS), was seen in the emergency department of our hospital because of chest pain. He had taken dual 
antiplatelet (clopidogrel $75 \mathrm{mg} / \mathrm{d}$, acetylsalicylic acid $100 \mathrm{mg} / \mathrm{d}$ ) therapy for 13 months and acetylsalicylic $(100 \mathrm{mg} / \mathrm{d})$ therapy for 15 months. On presentation, he was not taking any antiplatelet therapy. The patient was well until an hour before admission. He rated the pain at 10 on a scale of 0 to 10 , with 10 indicating the most severe pain. The blood pressure was $140 / 90 \mathrm{mmHg}$ in the right arm and $135 / 85 \mathrm{mmHg}$ in the left arm, and the other vital signs were normal. The lungs were clear. The 12-lead electrocardiogram showed ST-segment depression in leads $\mathrm{V}_{1}$ through $\mathrm{V}_{3}$, ST elevation in leads $\mathrm{V}_{5}, \mathrm{~V}_{6}, \mathrm{I}$. $300 \mathrm{mg}$ chewable acetylsalicylic acid and $180 \mathrm{mg}$ Ticagrelor were administered. Prompt revascularization with aspiration thrombectomy (Figure 1A pre-thrombectomy), restrored normal antegrade coronary perfusion within 90 minutes after the onset of pain, and tirofiban infusion was administered because of massive thrombus burden (Figure 1B postthrombectomy). Symptom was resolved after the procedure and $>70 \%$ ST-segment resolution was obtained (Figure 2). The peak troponin I and creatine kinase-MB levels were $28 \mathrm{ng} / \mathrm{mL}$ and $96 \mathrm{ng} / \mathrm{mL}$, respectively. The severely impaired inferior and inferolateal wall motion returned to normal within 5 days. The patient was discharged on the sixth day with dual antiplatelet therapy (acetylsalicylic acid $100 \mathrm{mg} /$ day, ticagrelor 90 mg b.i.d.).

\section{Discussion}

Stent thrombosis is associated with higher thrombus burden than thrombosis of native coronary arteries [1]. Some factors are prone to ST such as stent-related factors, procedure-related factors, patient-related factors, duration of antiplatelet therapy [2]. Endothelium grows over the struts in 2 to 4 weeks [3]. Prolonged dual antiplatelet therapy is imperative in patients with DES owing to delayed endothelialization. Hence BMS should be preferred before surgery. Some procedural factors are associated with ST such as stent-edge dissection, inadequate stent expansion and incomplete stent apposition. Comorbid risk factors are also important like diabetes mellitus, renal disease and impaired LV function. Early cessation of dual antiplatelet therapy and clopidogrel resistance are also important. In patients receiving a stent (BMS or DES) during percutaneous coronary intervention (PCI) for acute coronary syndrome (ACS), P2 $\mathrm{Y}_{12}$ inhibitor therapy should be given for at least 12 months (classI,B) [4, 5].

On account of delayed endothelialization, continuation of $\mathrm{P}_{2} \mathrm{Y}_{12}$ inhibitor therapy beyond 12 months may be considered in patients undergoing placement of DES (class II b, C) [4]. In patients receiving BMS for a non-ACS indication, $\mathrm{P}_{2} \mathrm{Y}_{12}$ inhibitor therapy should be given for a minimum of 1 month and ideally up to 12 months (class I, B) [4]. Owing to early endothelialization, very late stent thrombosis is rarely seen in patients with BMS. Thereby, prolonged dual antiplatelet therapy is not imperative after BMS implantation. In spite of knowledge about vascular endothelialization, our patient presented with BMS thrombosis 14 years after the implantation. To conclude, this case and similar cases suggest that we must investigate causes and prevention of late endothelialization [6, 7].

\section{References}

1. Pompa JJ, Bhatt DL. Percutaneous Coronary Intervention. In: Bonow RO, Mann DL, Zipes DP, Libby P, Braunwald E, editors. Braunwald's Heart Disease: Elsevier Saunders; 2012; pp: 1270-90.

2. Krishnaswamy A, Kapadia SR. Percutaneous Coronary Intervention. In: Griffin BP, editor. Manual of Cardiovascular medicine. Lippincott Williams \& Wilkins; 2013; pp: 1050-1.

3. Stone GW, Kirtane AJ. Bare Metal and Drug-Eluting Coronary Stents. In: Topol EJ, Teirstein PS, editors. Texbook of Interventional Cardiology. Elsevier Saunders; 2012; pp: 171-97.

4. Levine GN, Bates ER, Blankenship JC, Bailey SR, Bittl JA, Cercek B, Chambers CE, Ellis SG, Guyton RA, Hollenberg SM, Khot UN, Lange RA, Mauri L, Mehran R, Moussa ID, Mukherjee D, Nallamothu BK, Ting HH; American 
College of Cardiology Foundation; American Heart Association Task Force on Practice Guidelines; Society for Cardiovascular Angiography and Interventions. 2011 ACCF/AHA/SCAI Guideline for Percutaneous Coronary Intervention. A report of the American College of Cardiology Foundation/American Heart Association Task Force on Practice Guidelines and the Society for Cardiovascular Angiography and Interventions. J Am Coll Cardiol 2011 Dec 6; 58: e44-122.

5. Task Force on Myocardial Revascularization of the European Society of Cardiology (ESC) and the European Association for Cardio-Thoracic Surgery (EACTS) 1; European Association for Percutaneous Cardiovascular Interventions (EAPCI), Wijns W, Kolh P, Danchin N, Di Mario C, Falk V, Folliguet T, Garg S, Huber K, James S, Knuuti J, Lopez-Sendon J, Marco J, Menicanti L, Ostojic M, Piepoli MF, Pirlet C, Pomar JL, Reifart N, Ribichini FL, Schalij MJ, Sergeant P, Serruys PW, Silber S, Sousa Uva M, Taggart D. Guidelines on myocardial revascularization. Eur Heart J 2010; 31: 2501-55.

6. Lemesle G, Pinto Slottow TL, Waksman R. Very late stent thrombosis after baremetal stent implantation: case reports and review of the literature. J Invasive Cardiol 2009; 21: 27-32.

7. Aksu T, Başer K, Durukan MK, Şen T, Güray Ü. Very late thrombosis of a bare metal stent despite ongoing aspirin therapy after 10 years of implantation. Cumhuriyet Med J 2012; 34: 481-4. 